UDC 331.44

DOI: https://doi.org/10.32782/2224-6282/167-11

\begin{abstract}
Doronina Maya
Doctor of Economics, Professor,

Research Center for Industrial Development Problems of the National Academy of Sciences of Ukraine ORCID: https://orcid.org/0000-0001-8074-375X
\end{abstract}

Mykhailenko Daria

Candidate of Economics, Associate Professor, Research Center for Industrial Development Problems of the National Academy of Sciences of Ukraine ORCID: https://orcid.org/0000-0002-8420-6510

Дороніна М. С. доктор економічних наук, професор, Науково-дослідний центр індустріальних проблем розвитку Національної академії наук України ORCID: https://orcid.org/0000-0001-8074-375X

Михайленко Д. Г. кандидат економічних наук, доцент, Науково-дослідний центр індустріальних проблем розвитку Національної академії наук України ORCID: https://orcid.org/0000-0002-8420-6510

\title{
INFORMATION AND METHODOLOGICAL SUPPORT OF THE EQUILIBRIUM BETWEEN PROFESSIONAL MOBILITY AND QUALITY OF LIFE OF MANAGEMENT STAFF
}

The purpose of the article is the clarification of the content and functions of information and methodological support of the equilibrium between professional mobility and quality of working life of management staff. The main objectives of the article are systematization and clarification of the grounds for the comprehensive approach to a new and enriched subject of study, the choice of methods that correspond to the nature of the actual material, conditions and purpose of the particular study. The relevance of the research topic is determined by the lack of a paradigm for studying the equilibrium between professional mobility and quality of working life of management staff, the need for significant refinements of research and practical implementation of personnel management with unique knowledge, skills and abilities. The effectiveness of the manager's influence on the working activity of such subordinates largely depends on understanding the essence of their personal potential for professional mobility and quality of working life. Clarification of the main idea of the study, hypotheses of the principles, conceptual and categorical support, research methods of professional mobility and quality of working life need analysis and justification. The article offers a list of concepts and categories that can systematically reflect the basic coordinate system of the study, and to extend it in case of need. Professional mobility of management staff (individual employee, group, team, staff, enterprise) is recommended to be considered as its integrative quality, which combines, first, the formed internal need for success in life, which is manifested in activities, provides self-determination and self-realization in life and profession; secondly - the ability to work professionally, thirdly - the knowledge base of professional activity, fourthly, self-awareness of own professional mobility, formed on the basis of reflection on readiness for change in the profession; fifth - the desire to change oneself, own professional field, own living environment. Personality in the context of the purpose of the article is seen as an individual who occupies a certain position in society, performs a certain social role, is able to understand his dependence on his environment, and consciously ensure the mutual benefit of coexistence therewith. When writing the article, a system of classical empirical and theoretical methods of economic research was used, supplemented by the methods of the humanities.

Keywords: management staff, professional mobility, quality of working life, equilibrium, information and methodological support, terminology.

JEL classification: J6, M5

\section{ІНФОРМАЦИЙНО-МЕТОДИЧНЕ ЗАБЕЗПЕЧЕННЯ ЗБАЛАНСОВАНОСТІ ПРОФЕСІЙНОӤ МОБІЛЬНОСТІ І ЯКОСТІ ЖИТТЯ УПРАВЛІНСЬКОГО ПЕРСОНАЛУ}

\footnotetext{
Мета статті - уточнення змісту і функиій інформачійно-методичного забезпечення збалансованості професійної мобільності і якості трудового життя управлінського персоналу. Основними завданнями статті обрано систематизачію і уточнення підстав комплексного підходу до нового $і$ збагаченого предмету дослідження, до вибору методів, які відповідають характеру фактичного матеріалу, умовам і меті конкретного дослідження. Актуальність теми дослідження визначається відсутністю парадигми для дослідження збалансованості професійної мобільності $i$ якості трудового життя управлінського персоналу, потребою значних уточнень дослідження і практичної реалізаиіі управління персоналом з унікальними знаннями, вміннями і навичками. Результативність впливу керівника на трудову
} 
активність таких підлеглих значною мірою залежить від розуміння сутності їх особистісного потениіалу професійної мобільності і якості трудового життя. Уточнення головної ідеї дослідження, гіпотез принципів,, понятійно-категоріального забезпечення, методів дослідження професійної мобільності і якості трудового життя потребують аналізу і обтрунтувань. У статті запропоновано перелік понять і категорій, здатних системно відобразити основну систему координат дослідження, за необхідності - продовжити його. Професійну мобільність управлінського персоналу (окремого працівника, групи, колективу, команди, підприємства) рекомендується розглядати як (іï) інтегративну якість, що поєднує в собі, по-перше, сформовану внутрішню потребу в успішності життя, яка проявляється в діяльності, забезпечує самовизначення та самореалізацію в житті та професї; по-друге, - здібності до професійно діяльності, по-третє, - знаннєву основу професійної діяльності, по-четверте самоусвідомлення власної професійної мобільності, сформоване на основі рефлексії готовності до змін в професї; по-n'яте - прагнення змінити себе, професійне поле, життєве середовище. Особистість в контексті мети статті розглядається як індивід, щзо займає певне положення в суспільстві, виконує певну суспільну роль, здатний зрозуміти свою залежність від середовища, в якому перебуває, і свідомо забезпечувати взаємовигоду співіснування з ним. При написанні статті використано систему класичних емпіричних і теоретичних методів економічних досліджень, доповнену методами наук гуманітарного ичиклу.

Ключові слова: управлінський персонал, професійна мобільність, якість трудового життя, збалансованість, інформаційно-методичне забезпечення, терміносистема.

Articulation of the problem. Recovery of the national economy largely depends on the competence, professional mobility of managers of industrial enterprises. Currently, the classical methods of regulating the labor activity of the subordinates, which they successfully used in the past, need to be supplemented with new ones, borrowed from the disciplines of the humanities, and the development of the quality of their working life. Scientists, representatives of the disciplines of the humanities, began to actively work on the problems of professional mobility and quality of working life of staff. The essence and content of these characteristics are formulated by them depending on the disciplinary aspect, and methodological support is often presented only as a list of tools used by the scientist. The content of such tools is not consistent with the tasks, the reliability of which must be ensured, they remain out of scientists' attention.

Analysis of recent research and publications. Economic science and practice are quickly filled with situations of socio-economic or socio-psychological content, require the involvement of knowledge and recommendations of several scientific disciplines that deal with a team-member with high creative potential. The results of using the knowledge and abilities of such a person depend, firstly, on his active position, professional mobility at work, and secondly - on the characteristics of the employee's working environment, affecting his emotional state, form a desire or unwillingness to cooperate with colleagues, be tolerant or indifferent to the interests of company owners who provided him with the job. Currently, these characteristics are becoming critical for employees of the management system of any organization (including the manufacturing enterprise). It is their potential today that becomes the main resource for the effective functioning and development of the organization.

In connection with the above problems, there is a need for further development of management humanization and democratization in order to form a total workforce of the creative team. Scientists are faced with the task of ensuring the reliability of information and methodological tools for studying the equilibrium between professional mobility and quality of work life of managers. A comprehensive approach to the renewed and enriched subject of management can be justified by focusing on the recommendations of modern classics of methodological level in Philosophy, Sociology (e.g., V. Stepina [1], V. Bekha [2]). In the context of personnel management, certain ideas can be found in the monograph by L. Miliaeva [3]. However, the potential of tools of different disciplines, applied in the analysis of such a complex phenomenon in its quality and number of characteristics as the balance of professional mobility and quality of life of the management staff, requires more detailed research.

The purpose of the article is the clarification of the content and functions of information and methodological support of the equilibrium between professional mobility and quality of life of management staff.

Statement of basic materials. The trend of humanization of Economic Theory in general and in particular its special branch - the Theory of Management, is reflected in the works of Nobel laureates in economics, who received basic scientific qualifications in other disciplines. The list of publications, which presents methodological support for managing the quality of working life and professional mobility of managers by representatives of various scientific disciplines, is also quite significant. However, first, each article, monograph focuses on the characteristics of either their professional mobility or quality of working life. Secondly, they have almost no justification for the ways to combine the tools and technologies proposed in different sciences to solve the problem.

The analysis of dissertations submitted for defense in Ukraine and Russia for the period 2015-2017 showed that for the first time the characteristics of labor mobility and quality of working life of the staff (though without selecting a group of managers) were chosen for studying by O. Taraban [4]. The equillibrium between the development of professional mobility, the conditions and factors that affect it, and the quality of working life directly of managers using an interdisciplinary approach has not been studied, not even clearly articulated, although already understood.

To harmonize the research and management of the development of the quality of working life and professional mobility of managers, it is necessary to determine the conceptual foundations of their system analysis, in which the information and methodological component deserves special attention. After all, the reliability and constructiveness of theoretical conclusions and practical recommendations largely depend on its quality.

The problem of such a study has no paradigm. The relevant scientific foundations of its analysis are at the phenomenological stage. The current picture of the world (the main constructive coordinates that need to be studied) is not defined at the level of philosophy, theory or specific science. In this case, it is advisable to analyze the already published proposals for the construction of the concept of 
research of a fundamentally new subject of science $[5 ; 6]$.

The main idea of the research, hypotheses, conceptual and categorical support, principles, methods of systematic research of professional mobility and quality of working life of the concept need analysis and justification.

Preliminary analysis of information and methodological support for the study of quality of working life and professional mobility of staff, presented in publications of specialists in various scientific disciplines, will create the basis for a pilot set of tools for collecting information and developing on its basis methodological analysis of reserves for balanced development of managers' professional mobility and quality of their working life.

Since the quality of working life and professional mobility of a person are reflected in several scientific disciplines, it is necessary to find recommendations for combining their research technologies. It is in the conditions of using the interdisciplinary approach that the information-methodical base of the research deserves special attention. After all, each scientific discipline has its own terminological system, methods of information display of its subject, models of its analysis and organization, tools and technologies to influence it. Their systematization largely depends on the ability of the scientist to determine the patterns of the subject of study. The choice of specific methods depends on the nature of the actual material, the conditions and purpose of the specific study. The end result of such work is an ordered system of methods, which determines the place of each of them at a particular stage of the study, the content of techniques for working with theoretical and empirical material.

The list of tools of different disciplines used by scientists is quite significant (methodology, algorithm, program, etc.). Among them, attention to the concept of approach has recently increased. It is gradually becoming clear that it is currently impossible to objectively assess the reliability of scientific research without it. However, the recommendations for its use are not clearly defined, it is the least methodologically sound concept. Although everyone dealing therewith believes that the approach is more general in content than the method. The core of the approach consists of certain theoretical theses, assumptions or concepts. The approach serves as a theoretical basis for more specific and more complex methodological constructs. Abstracts of dissertations traditionally provide a list of research methods used by the author. According to their composition and content, opponents diagnose the scientific qualification of the applicant. He must qualitatively substantiate the need and features of the purpose of the tools of his research (method, approach, program, algorithm, etc.). Approaches are often included in their list, although later in the text the peculiarity of their content is not disclosed.

Comparing the definitions of the approach and method will help to concretize the features of this scientific tool. The analysis of the relevant literature showed that the approach in scientific research is a less formalized, less directive and at the same time meaningfully more voluminous methodological tool in comparison with the method. It is also more complex than the algorithm, program and other constructs of science.

As for the ratio of method, program and algorithm, the method is considered more complex in content construct. The program should be perceived as a set of unambiguous regulated actions. Certain programs may be part of the method as its most clearly defined parts.

An algorithm is a program, the implementation of which guarantees a successful result. The method, unlike the algorithm, does not guarantee the achievement of the goal. When choosing a research method, it is not assumed that it will necessarily provide a clearly objective result. The same method can be used in different conditions to solve different problems, and vice versa, one problem can be solved by different methods.

A method is a set of recommendations organized into a system. Recommendations being a part of a particular method have different levels of complexity and certainty. That is, they can both rigidly define the structure of activities, and play the role of recommended principles. In the latter case, the methods guide the activity, leaving enough space for creativity, without focusing on it in the program.

When comparing the approach and method, we can draw the following conclusion.

First, the approach is used in situations where a particular subject area of science is not methodologically provided. Given the appropriate philosophical education of the scientist, it is the approach that can give the scientific community the latest ideas. That is, a scientist who qualitatively argues approaches to a new problem, opens the way for other scientists to discover new truths. It is also possible that approaches have already been identified, but a systematic list of methods is not justified for them. This is also a constructive way of developing science.

Secondly, a specific approach is a less directive element of the methodological system compared to other scientific tools. As a rule, it almost always has or provides alternatives. Therefore, the concept of "approach" is often used in situations where it is not possible to use a single methodology (for example, in some humanities). In this case, it is necessary to justify the list of approaches.

Third, the approach is rather a methodological construct in terms of content and purpose. Because within one approach a certain set of methods can be used, for each of which it is necessary to clarify the content in the coordinates of the approach.

This situation can occur when there is a practical need to study a new, enriched subject, for which a research paradigm has not been created, i.e., it is at the phenomenological stage of forming a new direction of science.

Many scientists, analyzing the approach, explain its connection with methodology (for example, [7; 8]). $\mathrm{N}$. Ippolitova presents the analysis of the relationship between methodology and methodological approach. Methodology is traditionally perceived as the doctrine of scientific methods of cognition, as a system of scientific principles being the basis for research and choice of cognitive tools, methods and techniques of research. $\mathrm{N}$. Ippolitova draws attention to its hierarchical structure. The author recommends to focus on the idea of hierarchical classification of methodological approaches proposed by Ye. Yudin and I. Blauberg, highlighting the philosophical, general scientific, specific scientific and technological levels [7, p. 10].

The philosophical level of methodology determines the worldview approaches of the scientist to the process of cognition and transformation of reality. In determining 
its content, it is advisable to focus on the rules of creating a picture of the world. The order of its use and content in relation to socio-economic research are presented in the publication of M. Kyzym [9]. The general scientific level concentrates concepts that provide the scientist with the knowledge necessary for the general analysis of the studied phenomenon (most often specified in the analysis of complex system objects). At the specific scientific level, principles are selected, research methods characteristic of a certain scientific discipline are distinguished, and a paradigm is formulated. An example of its implementation is given in the work of O. Starokozhko [10].

Important ideas for substantiating the list of approaches in research methodology can be found in the publications of modern scientists who study the educational sphere of society. A selective analysis of their publications and dissertations over the past five years $[11 ; 12$, etc.] showed that almost every author in his study declares an orientation to the principles of dialectics and a systematic approach. In addition to them, synergetic, informational, culturological, process and other approaches are used in specific problem statements. Their list is quite large. However, the content of the approaches is not represented by all scientists. An exception is the research of authors of foreign versions of the organization of educational systems. The work of T. Krystopchuk deserves special attention in this regard [13].

Ensuring the equilibrium between professional mobility and quality of life of management staff is a relatively new subject of research, has a complex qualitative structure, requires justification of the prerequisites for creating a paradigm. Currently, in publications on management, the authors use either a systematic or a synergistic approach to solve this problem. Each of them has both advantages and limitations. The constructive functions of the system approach include the following: it allows to gain the understanding of the sources of system development, to find its ability to maintain order in the system from its own sources, to make forecasts based on continuing previous trends, to use information about the system to restore the previous order. Synergetics is useful because it explains the sources of formation of a new system. It focuses the scientist's attention on the permanence not of the state of the system, but on the permanence of its changes, gives an explanation of the need to perceive the chaotic state of the system as a prerequisite for the emergence of new previously unknown reserves of its preservation and development.
Professional mobility of management personnel of the enterprise is able to ensure its preservation and development provided a combination of traditions and innovations, maximum use of both existing productive forces and new ones, which are determined not so much using a logical scheme, but intuitive, creative, original. The combination of the advantages of the system and synergetic approach in the system-synergetic one creates the preconditions for determining the constructive technologies for streamlining the behavior of employees of the enterprise management system.

Given the above material, to pre-determine the system of information and methodological support for the study of professional mobility and quality of life of managers, the work of scientists from various scientific disciplines, presented in the abstracts of their dissertations was used. A total of 72 works was analyzed. The general list of methods used by the authors was divided into groups: methods of philosophy, general scientific methods, specific scientific methods, modeling methods, methods of statistical analysis and special specific methods due to the nature of the subject (Table 1).

As a result of grouping the entire list of methods used by degree seekers, the following results were obtained. The first group included 4\% of all the analyzed research methods, the second $-33.6 \%$, the third $-32.1 \%$, the fourth $-8.7 \%$, the fifth $-16.8 \%$, the sixth $-4 \%$.

The philosophical aspect of the research is presented in the dissertations by the dialectical method of research. In general scientific methods, the main attention of scientists is focused on methods of systematization, generalization, various methods of analysis and abstraction (respectively $22 \% ; 21.7 \% ; 19.5 \%$ of the total number of methods in this group). In specific scientific methods, a significant share was given to methods of testing, observation, experiment - 16\% each; $13.6 \%$ - questionnaires, surveys and expert assessments and $11 \%$ - methods of surveys and expert assessments. There were almost no methods of selfassessment, interviews, competent judges (only one case).

With regard to modeling methods, the authors of the analyzed dissertation research reported in abstracts that their work presents models of specific situations. At the same time, neither the content of such situations nor the justifications for choosing the type of model were provided. In the methods of statistical analysis, the instruments of mathematical statistics and correlation-regression analysis, statistical and economic-statistical models $(25-26 \%$ of the total) received the largest share. About $13 \%$ of scientists

Generalization of Research Methods of the Dissertation Subject

Table 1

\begin{tabular}{|l|c|l|}
\hline \multicolumn{1}{|c|}{ Methods } & & \multicolumn{1}{c|}{ Contents of methods } \\
\hline Methods of Philosophy & $4 \%$ & dialectical method \\
\hline General Scientific Methods & $33.6 \%$ & $\begin{array}{l}\text { systematization, generalization, different methods of analysis and abstraction } \\
(22 \% ; 21.7 \% \text { 19.5\% of the total number of methods in this group) }\end{array}$ \\
\hline Specific Scientific Methods & $32.1 \%$ & $\begin{array}{l}16 \% \text { of testing, observation, experiment; 13.6\% - questionnaires, surveys and expert } \\
\text { assessments; } 11 \% \text { survey methods and expert assessments }\end{array}$ \\
\hline Modeling Methods & $8.7 \%$ & $\begin{array}{l}\text { the authors report in the abstracts that their works present models of specific situations, } \\
\text { although, neither the content of such situations nor the justifications for choosing } \\
\text { the type of model are given }\end{array}$ \\
\hline Methods of Statistical Analysis & $16.8 \%$ & $\begin{array}{l}25-26 \% \text { correlation-regression analysis, statistical and economic-statistical models, } \\
13 \% \text { of scientists used cluster and factor analysis }\end{array}$ \\
\hline Special Specific Methods & $4 \%$ & $33 \%$ graphical and tabular methods \\
\hline
\end{tabular}


used cluster and factor analysis tools. In the group of special methods aimed at the integrated presentation of the results of the dissertation research, the same proportion $(33 \%)$ received graphical and tabular methods.

Since the scientific school of Kharkiv National Economic University named after S. Kuznets has experience in critical analysis and substantiation of methodological and methodical research tools in the field of economics, in addition to the analysis of abstracts, the recommendations of scientists of this higher education institution presented in their latest publications were summarized. The publications of both well-known scientists (for example, T. Lepeiko [14]) and scientists who recently defended their dissertations and used the recommendations of humanitarian disciplines to solve problems of management of industrial organizations were analyzed (among them S. Holubev [15], A. Polubedova [16]).

As for the publication of T. Lepeiko, it is possible to take the idea of forming a comprehensive study of a complex subject by nature from its consept. For example, the author gives a rationale for the main stages of formation of a system of indicators needed to analyze a new problem that has arisen in the work of the enterprise. An example of presenting the characteristics of the main research methods and tools is provided in an accessible form in the publication. The author's recommendations on the expediency of allocating a certain hierarchy of decisionmaking levels, each of which is responsible for solving specific key issues of the problem, which are within its competence are convinsing [14, p. 176].

The analysis of new research results of young scientists in order to determine which of them can be included in the list of those being able to provide new theoretical and practical new recommendations, gave the following results. The algorithm of construction of the terminological system for the performance of interdisciplinary researches of social reserves of collective labor potential offered by S. Holubev can be used for construction of system conceptual and categorical maintenance of the analysis of characteristics of quality of working life and professional mobility. A. Polubedova reveals the procedures of supplementing the traditional paradigm of personnel management with behavioral components and enriching the tools of analysis of its reserves with new diagnostic technologies. For example, in the study of the equilibrium between professional mobility and quality of working life of managers, we can use her assessment of the balance of development of a multidimensional phenomenon using the norms of the "golden section" and the recommendations of socionics.

Authoritative scientist, Doctor of Philosophy, A. Moiseev believes that specialization and differentiation of sciences, expansion of fundamentals and applied research, the emergence of projects integrating scientific and non-scientific knowledge, expansion of various expert systems and expert groups indicate the next stage of science, the stage of "new knowledge production" $[17, \mathrm{p} .45]$. This trend is accompanied by increasing attention to multidisciplinary and interdisciplinary research, it is based on the accelerated increase in the number of special scientific disciplines. The author cites the following data: "In the very first universities, founded in the XIII century, there were seven disciplines. In 1950 there were already 54 disciplines. Their number is increasing very rapidly. In 2000 there were more than 8,000 disciplines" [17, p. 41].

Additional analysis of publications of methodological and philosophical content showed that in determining the general coordinates of multiparametric and complex in its qualitative nature phenomenon, it is advisable to combine ontological, epistemological, axiological aspects to create a system of appropriate cognitive schemes. Since in the further work it is planned to develop methodological support for the formation of a professionally mobile aggregate workforce group of managers, it is advisable to test the possibility of using the recommendations of the theory of spiral dynamics of consciousness in order to diagnose real conscious motivations for teamwork. Its technologies have already been partially tested by the author.

In research, it is also advisable to follow a systemsynergetic approach, since both the quality of working life and professional mobility of staff are systemic entities that dynamically interact with each other and with the environment. In the management of their balanced development it is necessary to take into account the corresponding reaction of each system when changing the individual components of another.

The choice of approach depends on the subject of research. Useful information for this choice can be obtained from Table 2.

Complicating the subject of research requires the use of knowledge and technology of various disciplines.

Table 2

Approaches Used in Socio-Economic Research

\begin{tabular}{|l|l|}
\hline \multicolumn{1}{|c|}{ Approach } & \multicolumn{1}{c|}{ Essence and Peculiarities } \\
\hline Process & $\begin{array}{l}\text { The process approach to management is a series of interrelated management functions, which is a continuous } \\
\text { process. This concept, which means a big turn in management thought, is widely used today. The management } \\
\text { process consists of four interrelated functions: planning; organizations; motivation; control }\end{array}$ \\
\hline Situational & $\begin{array}{l}\text { The situational approach focuses on the fact that the suitability of different management methods is determined by } \\
\text { the specific situation. Since there are a huge number of factors both in the firm and in the external environment } \\
\text { there is no better way to manage the facility. The most effective method in a particular situation is the method that } \\
\text { best suits the situation and adapted to it }\end{array}$ \\
\hline Monographic & $\begin{array}{l}\text { A case study method; comprehensive complex analysis of a single object, considered as typical for this class of } \\
\text { phenomena }\end{array}$ \\
\hline Transdisciplinary & $\begin{array}{l}\text { An approach that opens wide opportunities for the interaction of many disciplines in solving complex problems } \\
\text { of nature and society. It allows scientists to officially go beyond their discipline without fear of being accused of } \\
\text { amateurism. Depending on the scope and combination scientists will use other disciplines in their disciplinary } \\
\text { research, transdisciplinarity will be called multidisciplinarity, pluridisciplinarity, interdisciplinarity }\end{array}$ \\
\hline
\end{tabular}


According to N. Khmelkova, the growing complexity of management tasks creates completely new challenges for education in the field of management, requires the formation of a new generation of managers of such competencies that would allow them to overcome new problems of the modern world. First of all, the subjects of new competencies include a systematic approach to problem solving and dialectical thinking. Describing the model of a modern effective manager, N. Khmelkova refers to the opinion of another well-known scientist: "Transdisciplinarity is a fundamentally new view of understanding the subject area of science beyond disciplinary boundaries". In particular, E. Kniazeva points out that transdisciplinarity characterizes such studies that go beyond the boundaries of many disciplines, go beyond specific disciplines. This creates a holistic vision of the subject of study. Transdisciplinary research is characterized by the transfer of cognitive schemes from one disciplinary field to another, the development and implementation of joint research projects" [19, p. 83]. R. Prima in the article on the scientific principles of professional mobility of the specialist, comments on the relevance of his publication as follows: "The chosen direction of research is due to the lack of scientific research in this purely pedagogical aspect, one-sided consideration of the problem (mainly economic or social), lack of interdisciplinary systems to this complex phenomenon" [20, p. 127].

The personal potential of employees involves its analysis at the level of the individual employee and the team. A new concept can be created using a terminological system (Fig. 2.2), which will provide the construction of technology combining methods of different sciences. Given the topic of the article, it is advisable to pay detailed attention to clarifying the terms "professional mobility" and "personality".

Professional mobility of management staff (individual employee, group, team, staff, enterprise) - is its integrative quality, which combines, first, the formed internal need for success in life, which is manifested in activities, provides self-determination and self-realization in life and profession; secondly, - ability to professional activity, thirdly, - knowledge base of professional activity, fourthly

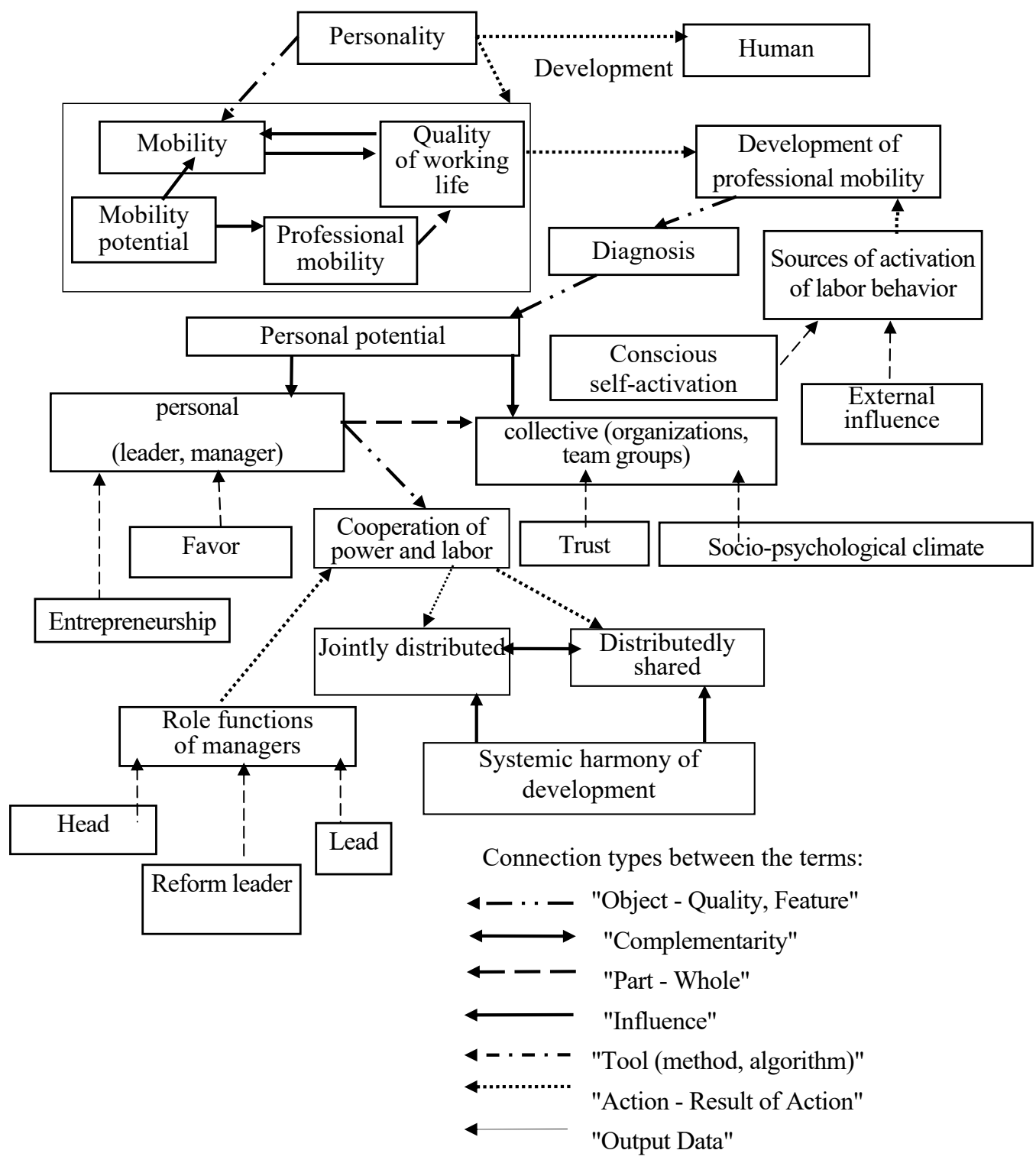

Fig. 1. Terminology System for Studying Professional Mobility of Management Staff 
self-awareness of own professional mobility, formed on the basis of reflection of readiness for changes in profession; fifth - the desire to change oneself, own professional field, own living environment.

Personality is an individual who occupies a certain position in society, performs a certain social role, is able to understand the interdependence of man and his environment, and consciously ensure the mutual benefit of their coexistence.

Conclusions. The equilibrium between professional mobility and quality of life of management staff can ensure sustainable development of enterprises. Its studying shall create the basis for maintaining and developing such a balance by improving information and methodological support. In addition, we can recommend to the traditional list of methods to perform analysis and testing of technology for diagnosing personal and collective socionic types, assessment of personal sources of professional mobility of team members using standards of spiral dynamics of Graves' consciousness, assessment of equilibrium between professional mobility and quality of life of management staff, conditions and factors that affect them, using the standard of "golden section".

\section{References:}

1. Stepin V.S. (2003) Samorazvivaiushchiesia sistemy i postneklassicheskaia ratsionalnost [Self-Developing Systems and Postnonclassical Rationality]. Voprosy Filosofii, no. 8, pp. 5-17.

2. Bekh V.P. (1999) Sotsialnyi orhanizm krainy [Social Organism of the Country]. Zaporizhzhia: ZDU, $186 \mathrm{p}$.

3. Miliaeva L.G., Dambovskaia A.A. (2011) Aktualnye problemy kadrovogo menedzhmenta organizatsii: monografiia [Actual Problems of Personnel Management of the Organization: Monograph]. Altaiskii Gosudarstvennyi Universitet, BTI. Biisk: izdatelskii dom Altaiskogo Gosudarstvennogo Universiteta, 193 p.

4. Taraban O.V. (2006) Soderzhanie i funktsii protsessa vnutrifirmennoi mobilnosti [Content and Functions of the Intra-Firm Mobility Process]. Zhurnal Izvestiia Irkutskoi gosudarstvennoi ekonomicheskoi akademii, no. 5, pp. 90-92.

5. Heiman O.A. (2009) Nelineinost ekonomiki i neravnomernost razvitiia regionov: monohrafiia [Nonlinearity of Economy and Uneven Development of Regions: Monograph]. Kharkiv: FLP Liburkina L.M. Izdatelskii Dom «YNZhEK», 428 p.

6. Lytovchenko I.V. (2011) Rozvytok profesiinoi kompetentnosti upravlinskoho personalu [Development of Professional Competence of Managerial Staff]: avoreferat dissertatsii kandidata ekonomicheskikh nauk: 08.00.07. Kharkiv, 20 p.

7. Ippolitova N.V. (2009) Vzaimosviaz poniatii «metodologiia» i «metodologicheskii podkhod» [The Relationship Between the Concepts of "Methodology" and "Methodological Approach"]. Vestnik Yuzhno-Uralskogo gosudarstvennogo universiteta. Seriia Obrazovanie. Pedagogicheskie Nauki, no. 13, pp. 9-15.

8. Kelman M.S. (2009) Spivvidnoshennia metodu i metodolohichnoho pidkhodu u iurydychnii nautsi [The Ratio of Method and Methodological Approach in Legal Science]. Naukovyi visnyk Lvivskoho derzhavnoho universytetu vnutrishnikh sprav, no. 3 , p. 314.

9. Kyzym M.O., Doronina M.S. (2017) World View in Economic Science. The Problems of Economy, no. 3, pp. $227-232$.

10. Starokozhko O.M. (2016) Rodovi vzaemozviazky kontseptiv «paradyhma» ta «doslidnytskyi pidkhid» [Generic Relationships Between the Concepts of "Paradigm" and "Research Approach"]. Naukovi zapysky Berdianskoho derzhavnoho pedahohichnoho universytetu. Pedahohichninauky, no. 1, pp. 237-244.

11. Ivanchenko Ye.A. (2005) Formuvannia profesiinoi mobilnosti maibutnikh ekonomistiv u protsesi navchannia u vyshchykh navchalnykh zakladakh [Formation of Professional Mobility of Future Economists in the Process of Studying in Higher Educational Institutions]: avtoreferat dysertatsii kandydata pedahohichnykh nauk: 13.00.04, Odesa, $21 \mathrm{p}$.

12. Klymenko Yu.A. (2011) Profesiina mobilnist maibutnikh uchyteliv u krainakh Yevrosoiuzu [Professional Mobility of Future Teachers in EU Countries]: avtoreferat dysertatsii kandydata pedahohichnykh nauk: 13.00.04, Uman, 20 p.

13. Krystopchuk T.Ye. (2014) Tendentsii rozvytku pedahohichnoi osvity v krainakh Yevropeiskoho Soiuzu [Trends in the Development of Pedagogical Education in in EU Countries]: avtoreferat dysertatsii doktora pedahohichnykh nauk: 13.00.04, Kyiv, 39 p.

14. Lepeiko T.I., Kryvobok K.V. (2016) Udoskonalennia instrumentiv adaptatsii pidpryemstv do vplyvu konkurentnoho seredovyshcha [Improving the Tools of Adaptation of Enterprises to the Influence of the Competitive Environment]. Biznes Inform, no. 12, pp. 176-181.

15. Holubev S.M. (2016) Diahnostyka sotsialnykh rezerviv rozvytku kolektyvnoho trudovoho potentsialu [Diagnosis of Social Reserves for the Development of Collective Labor Potential]: avtoreferat dysertatsii doktora pedahohichnykh nauk: 08.00.07, Kharkiv, 20 p.

16. Polubedova A.O. (2013) Formuvannia upravlinskoho vplyvu na trudovu povedinku personalu [Formation of Managerial Influence on the Labor Behavior of Staff]: avtoreferat dysertatsii doktora pedahohichnykh nauk: 08.00.04, Kharkiv, 20 p.

17. Moiseeva A.P. (2013) K voprosu o sootnoshenii poniatii mezhdistsiplinarnosti i transdistsiplinarnosti v nauchnom poznanii [To the Question of the Relationship Between the Concepts of Interdisciplinarity and Transdisciplinarity in Scientific Knowledge]. Vestnik Tomskogo gosudarstvennogo universiteta. Filosofia. Sotsiologiia. Politologiia, no. 4 (24), pp. 41-48.

18. Doronwna M.S., Mykhailenko D.H., Polubedova A.A. (2013) Tekhnologiia sotsialno-ekonomicheskikh nauchnykh issledovanii (skhemy i primery): uchebnoe posobie [Technology of Socio-Economic Research (Diagrams and Examples): Textbook]. Kharkiv: ID «YNZhEK», $170 \mathrm{p}$.

19. Khmelkova N.V. (2015) Transdistsiplinarnaia model sovremennogo effektivnogo menedzhera [Transdisciplinary model of a modern effective manager]. Upravlenie personalom, no. 4, pp. 82-89.

20. Prima R.M. (2008) Profesiina mobilnist fakhivtsia iak naukova problema. Pedahohika, psykholohiia ta medyko-biolohichni problemy fizychnoho vykhovannia i sportu: monohrafiia / za red. S. Yermakova [Professional Mobility of a Specialist as a Scientific Problem. Pedagogy, Psychology and Medical and Biological Problems of Physical Education and Sports: Monograph / ed. by S. Yermakova]. Kharkiv, pp. 127-132.

\section{Список викорстаних джерел:}

1. Степин В.С. Саморазвивающиеся системы и постнеклассическая рациональность. Вопросы философии. 2003. № 8. C. $5-17$.

2. Бех В.П. Соціальний організм країни. Запоріжжя : ЗДУ, 1999. 186 с.

3. Миляева Л.Г., Дамбовская А.А. Актуальные проблемы кадрового менеджмента организации : монография. Алт. гос. Ун-т, БТИ. Бийск : изд-во Алт. гос.техн.ун-та. 2011. 193 с. 
4. Тарабан О.В. Содержание и функции процесса внутрифирменной мобильности. Журнал Известия Иркутской государственной экономической академии. 2006. Вып. № 5. С. 90-92.

5. Гейман О.А. Нелинейность экономики и неравномерность развития регионов : монография. Харьков : ФЛП Либуркина Л. М. ИД «ИНЖЕК». 2009. 428 с.

6. Литовченко І.В. Розвиток професійної компетентності управлінського персоналу : автореф. дис. ... канд. екон. наук : 08.00.07. Харків, 2011. 20 с.

7. Ипполитова Н.В. Взаимосвязь понятий «методология» и «методологический подход». Вестник Южно-Уральского государственного университета. Серия Образование. Педагогические науки. 2009. № 13 (146). С. 9-15.

8. Кельман М.С. Співвідношення методу і методологічного підходу у юридичній науці. Науковий вісник Львівського держсавного університету внутрішніх справ. 2009. Вип. 3. С. 314.

9. Kyzym M.O., Doronina M.S. World View in EconomicScience. The Problems of Economy. 2017. № 3. C. $227-232$.

10. Старокожко О.М. Родові взаємозв' язки концептів «парадигма» та «дослідницький підхід». Наукові записки Бердянського держсавного педагогічного університету. Педагогічнінауки. 2016. Вип. 1. С. 237-244.

11. Іванченко Є.А. Формування професійної мобільності майбутніх економістів у процесі навчання у вищих навчальних закладах : автореф. дис. ... канд. пед. наук : 13.00.04. Одеса, 2005. 21 с.

12. Клименко Ю.А. Професійна мобільність майбутніх учителів у країнах Євросоюзу: автореф. дис. ... канд. пед. наук : 13.00.04. Умань, 2011. $20 \mathrm{c.}$

13. Кристопчук Т.Є. Тенденції розвитку педагогічної освіти в країнах Європейського Союзу: автореф. дис ... д-ра пед. наук: 13.00.04. Київ, 2014. 39 с.

14. Лепейко Т.І. Кривобок К.В. Удосконалення інструментів адаптацій підприемств до впливу конкурентного середовища. Бізнес Інформ 2016. №12. С. 176-181.

15. Голубєв С.М. Діагностика соціальних резервів розвитку колективного трудового потенціалу: автореф. дис. ... канд. ек. наук : 08.00.07. Харків, 2016. 20 с.

16. Полубєдова А.О. Формування управлінського впливу на трудову поведінку персоналу: автореф. дис. ... канд. ек. наук: 08.00.04. Харків, 2013. 20 c.

17. Моисеева А.П. К вопросу о соотношении понятий междисциплинарности и трансдисциплинарности в научном познании. Вестник Томского государственного университета. Философия. Соџиология. Политология. 2013. № 4 (24). С. 41 -48.

18. Доронина М.С., Михайленко Д.Г., Полубедова А.А. Технология социально-экономических научных исследований (схемы и примеры) : учебное пособие. Харьков : ИД «ИНЖЕК», 2013. 170 с.

19. Хмелькова Н.В. Трансдисциплинарная модель современного эффективного менеджера. Управление персоналом. 2015. № 4. C. 82-89.

20. Пріма Р.М. Професійна мобільність фахівця як наукова проблема. Педагогіка, психологія та медико-біологічні проблеми фізичного виховання і спорту : монографія / за ред. С. Єрмакова. Харків, 2008. С. 127-132. 